\title{
Tree rings detect earthworm invasions and their effects in northern Hardwood forests
}

\author{
Evan R. Larson · Kurt F. Kipfmueller • \\ Cindy M. Hale $\cdot$ Lee E. Frelich $\cdot$ Peter B. Reich
}

Received: 15 November 2008/Accepted: 1 July 2009/Published online: 14 July 2009

(C) Springer Science+Business Media B.V. 2009

\begin{abstract}
Invasions of European earthworms into the forests of northern North America are causing dramatic changes in forest floor structure, vegetation communities, biogeochemical cycling, and site hydrology. However, long-term studies on the effects of invasive earthworms are limited because little data exist on the timing and rate of earthworm invasion at specific sites. We successfully used tree rings to identify the timing of earthworm invasions and the effects of earthworm activity on the Acer saccharum
\end{abstract}

E. R. Larson $(\bowtie) \cdot$ K. F. Kipfmueller

Minnesota Dendroecology Laboratory, Department of Geography, University of Minnesota-Twin Cities, 414 Social Sciences Tower, 267-19th Avenue South, Minneapolis, MN 55455, USA

e-mail: larsonev@uwplatt.edu

Present Address:

E. R. Larson

Department of Social Sciences/Geography, University of Wisconsin-Platteville, 1 University Plaza, Platteville, WI 53818, USA

C. M. Hale

The Natural Resources Research Institute, Center for Water and the Environment, University of Minnesota Duluth, 5013 Miller Trunk Highway, Duluth, MN 55811, USA

L. E. Frelich · P. B. Reich

Department of Forest Resources, University of

Minnesota-Twin Cities, 1530 North Cleveland Avenue,

Saint Paul, MN 55108, USA overstory of two recently invaded sites in northern Minnesota, thereby establishing a method to date earthworm invasions at other sites. In addition to identifying a tree-ring signature related to earthworm invasion, we found trees growing in invaded conditions were more sensitive to drought than trees growing in earthworm-free conditions. Increased drought sensitivity by $A$. saccharum has important implications for possible range shifts under climate change scenarios that include increasing drought frequency and severity.

\section{Keywords Acer saccharum . \\ Climate-tree growth relationship . \\ Dendroecology $\cdot$ Earthworm invasion . \\ European earthworms $\cdot$ Northern Minnesota}

\section{Introduction}

The ecological effects of invasive species on native ecosystems are of paramount concern among conservation biologists and ecologists and pose one of the greatest challenges faced by land managers today. European earthworms have only recently been recognized as an exotic threat for the deciduous forests of northern North America, yet the changes wrought by these ecosystem engineers have likely been taking place for decades and are fundamentally altering the structure and function of these systems. 
Prior to a decade ago, relatively little attention was given to the role of exotic earthworms in forest ecosystems, with most earthworm-related research focused on their roles in nutrient cycling and the benefits of having viable earthworm populations in agricultural settings (Lee 1985). The focus of earthworm research began to change following observations of dramatic declines in forest floor thickness in deciduous forests of northern Minnesota that were eventually linked to the invasion of these forests by European earthworms (Alban and Berry 1994). Soon after this, exotic earthworm invasions into forested communities were documented in Alberta, Canada (Scheu and Parkinson 1994b) and New York State, USA (Burtelow et al. 1998), and eventually throughout the Great Lakes Region (Frelich et al. 2006; Tiunov et al. 2006). In most cases, the invasion of earthworms into previously earthworm-free forest environments resulted in a clear line moving through the forest, in front of which the forest floor appeared relatively unchanged, but behind which the litter layer was eliminated and the abundance and diversity of understory vegetation was diminished (Gundale 2002; Bohlen et al. 2004a; Bohlen et al. 2004c; Hale et al. 2005b, 2006; Frelich et al. 2006). The longerterm effects of these changes in ecosystem function and on the overstory vegetation community, however, are largely unknown (Bohlen et al. 2004b). A broader temporal perspective is required to observe the effects of earthworms on the vegetation communities of northern forests and to explore the implications that these changes hold for land management.

The potential for studying the long-term ecological effects of European earthworms on northern deciduous forests is currently limited by a lack of data describing the timing of invasions at specific sites, the rates at which invasion fronts advance across the landscape, and the environmental factors that affect these processes. Understanding these aspects of earthworm invasions will be critical to develop long-term strategies and management plans for North American forest ecosystems in the presence of European earthworms (Bohlen et al. 2004c). A method is needed to identify the location and timing of past invasion fronts across the landscape (Frelich et al. 2006; Holdsworth et al. 2007). Our research examined the effects of known earthworm invasions on the overstory vegetation of two deciduous forest stands in northern Minnesota to identify and describe an earthworm-related tree-ring signature that could be used to determine the date of earthworm invasions at other sites. Simultaneously, this work documented the impacts of earthworm colonization on the growth of mature trees in invaded stands.

\section{Methods}

Study area

The study area lies along the north shore of Leech Lake in north-central Minnesota (Fig. 1a). Our sites were located in sugar maple (Acer saccharum, Marshall)basswood (Tilia americana, Linnaeus) forests with clear, active earthworm invasion fronts (Hale et al. 2005a, b, 2006). Additional canopy tree species present included yellow birch (Betula alleghaniensis, Britton) and paper birch (Betula papyrifera, Marshall). Ironwood (Ostrya virginiana, K. Koch), American elm (Ulmus americana, Linnaeus), and red oak (Quercus rubra, Linnaeus) were also present in the subcanopy and sapling layers. The area was selectively logged during the late 1800s and early 1900s. The soil is a deep, well-drained and light-colored Eutroboralf (Warba series) associated with the Guthrie Till Plain (USDA 1997). Where earthworms have not yet invaded, the forest floor is intact and on average $10 \mathrm{~cm}$ thick with $\mathrm{O}_{\mathrm{i}}, \mathrm{O}_{\mathrm{e}}$, and $\mathrm{O}_{\mathrm{a}}$ layers. The $\mathrm{O}$ horizon has been eliminated where earthworms are present (Hale et al. 2005a). Mean annual precipitation is $65.2 \mathrm{~cm}$, mean annual temperature is $4.3^{\circ} \mathrm{C}$ and mean monthly temperature ranges from $19.9^{\circ} \mathrm{C}$ in July to $-14.5^{\circ} \mathrm{C}$ in January at the nearby Leech Lake Dam climate station (Easterling et al. 1996).

Five species of European earthworms were present in the study area: Dendrobaena octaedra, Aporrectodea spp., Lumbricus rubellus, and Lumbricus terrestris were found at both sites, while Octolasion tyrtaeum was present only at Section 19 (Fig. 1a, b; Hale et al. 2005a). Each species of earthworm has a specific set of foraging and burrowing behaviors that result in differential effects on the structure of the forest floor and litter layer. The overall similarity between the earthworm assemblages at these sites suggests that the effects of invasion should be similar in both forests. For a comprehensive description of the earthworm assemblages at these sites see Hale et al. (2005a). 


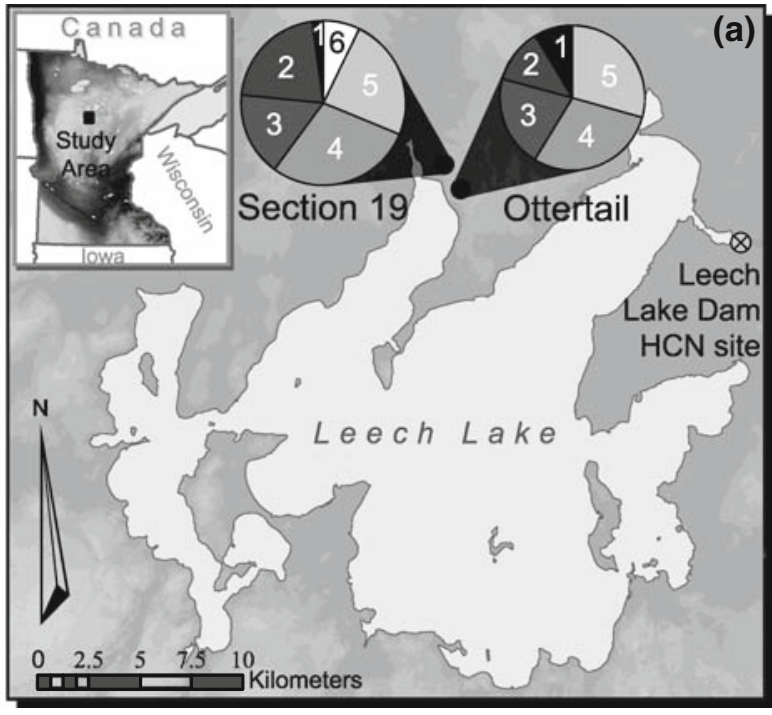

(c)

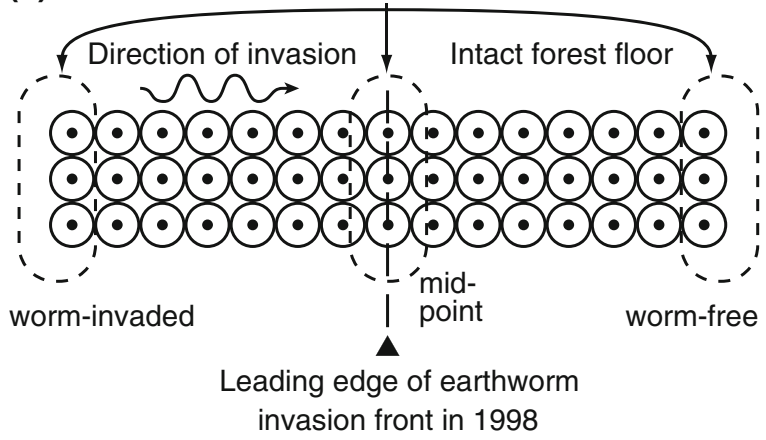

Fig. 1 The a study site locations and relative earthworm biomass, b earthworm biomass (ash-free dry g/ $\mathrm{m}^{2}$, Hale et al. 2004) relative to the earthworm invasion front, and c sample tree search areas relative to the visible leading edge of earthworm invasion at each site in the Chippewa National Forest in north central Minnesota, USA. Pie charts show the relative mean earthworm biomass for the species group present at each site in year 2000 and are sized in proportional to mean total earthworm biomass. Numbers in the Section 19 pie chart

Field and laboratory methods

A permanent transect of 45 plots was placed perpendicularly to the earthworm invasion front at both sites in 1998 by Hale et al. (2005a). For this study, we collected increment core samples from maple trees at three points along this transect: ahead of the location of the earthworm invasion front in 1998 (earthwormfree conditions); along the 1998 invasion front (midpoint conditions); and behind the location of the invasion front in 1998 (earthworm-invaded conditions; Fig. 1c). Our search areas included the three

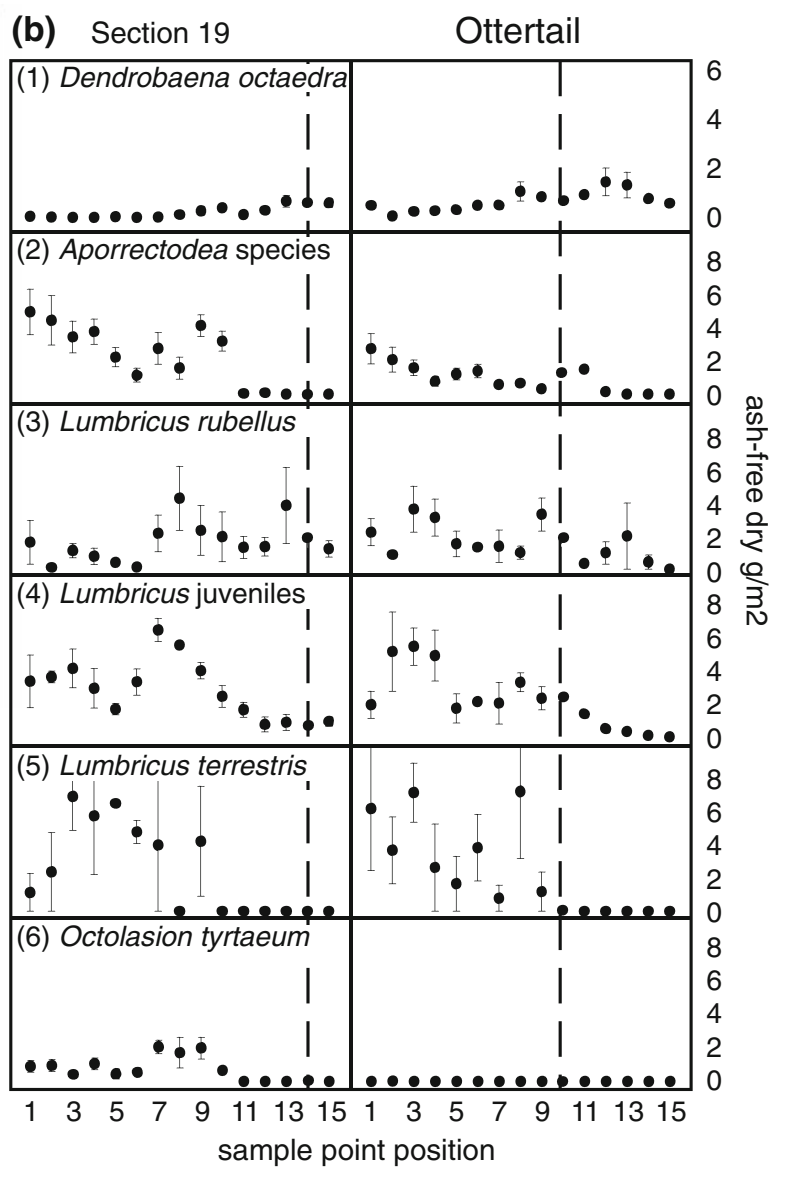

correspond to the numbers listed by each species in panel $\mathbf{b}$. The vertical dashed lines in $\mathbf{b}$ indicate the position of the leading edge (point where the forest floor had been completely eliminated) for each site in year 2000. The $\mathbf{c}$ search areas for trees growing in earthworm-invaded conditions, mid-point conditions, and earthworm-free conditions were delineated with respect to the permanent plots (indicated by the grid of circles) set up at each site by Hale et al. (2005a) in 1998

plots at each point along the permanent transect and extended ca. $20 \mathrm{~m}$ beyond the outer plots for total search areas ranging from $700-1,000 \mathrm{~m}^{2}$ at each point along the transect (Fig. 1c). This effectively provided us with tree-ring data from two control areas (the earthworm-free and mid-point conditions) and one test area (the earthworm-invaded conditions) at each site. In each collection area we identified living canopy maple trees to sample that showed no evidence of recent canopy disturbances. This was done to avoid the potential "noise" that could be introduced to the tree-ring sequences by growth 
releases or suppressions related to canopy disturbances (Lorimer and Frelich 1989) and that could mask the effects of earthworms on patterns of tree growth. Single increment cores were collected from maple trees growing in the earthworm-free and earthworm-invaded sites at Ottertail for a pilot study in 2004, and two increment cores were collected from each tree at the mid-point of Ottertail and at all three areas of Section 19 in 2006.

The cores were dried, glued into core mounts, and prepared for analysis using a razor blade to obtain a preliminary surface and progressively finer grit sand paper to finish the surface of each core to a high polish (Stokes and Smiley 1996). The rings of each core were counted and visually crossdated using a list of marker rings (i.e., conspicuously narrow rings) common to multiple trees at the site (Yamaguchi 1990). Cores that could not be satisfactorily dated were excluded from subsequent analyses. The rings of all dated cores were measured to the nearest $0.001 \mathrm{~mm}$ using a Velmex slide micrometer interfaced with measure J2X software (Voortech Consulting 2005). We assessed our crossdating accuracy using the computer program COFECHA v6.06P (Holmes 1983; Grissino-Mayer 2001), and where necessary, made corrections to the measurement series using the program EDRM v6.0P (Holmes 1999).

We developed standardized ring-width chronologies for each of the three sampling locations at both sites for a total of six chronologies. Our standardization process began by visually inspecting each individual tree ring-width series to determine the forest conditions under which the tree likely established (e.g., in full light under a gap or in shaded understory conditions) and the timing of its canopy ascension (Lorimer et al. 1988). To minimize the effects of growth suppressions and releases due to gap dynamics, we truncated all of our series to the period after which all trees included had attained a canopy position. Truncating the ring-width series also effectively removed growth trends related to juvenile growth, thereby eliminating the necessity of using negative exponential curves or linear regressions as commonly used in the standardization process (Fritts 1976). We considered standardizing our ring-width data using a model developed for closed-canopy ringwidth analyses (e.g., cubic splines, Cook and Peters 1981), but decided that the effects of earthworm invasion on tree ring-width patterns could be similar to the expressions of interior deciduous forest dynamics and removed from the final chronologies using this approach. We therefore chose the more conservative approach of standardizing each ringwidth series by dividing the measurement of each year by the mean of the series. The ring-width index (RWI) of all series at each site were averaged by year to create standardized RWI chronologies for each site. We used the computer program ARSTAN to conduct our standardizations (Cook 1985).

Identification of an earthworm invasion tree-ring signature

The primary goal of this study was to identify patterns in ring width related to the known invasion of our sites by European earthworms, but tree growth in mature deciduous forests is commonly affected by other factors, particularly gap dynamics (e.g., Runkle 1981; Foster 1988; Lorimer and Frelich 1989). We therefore assessed the growth patterns exhibited by each tree (based on the mean of the two ring-width series for each tree) for release events that would likely be associated with canopy disturbances. We defined a release event as the first year of a 15-year window in the ring-width series that showed a $200 \%$ increase in mean ring width relative to the previous 15 years of mean ring width (Lorimer and Frelich 1989; Frelich 2002). We then summed the number of release events by decade for each of the six sites to determine if any stand-level disturbances had occurred that could obscure an earthworm-related tree-ring signature.

To isolate the earthworm-related ring-width signature, we first plotted and inspected the annual RWI chronologies and the RWI chronologies filtered using a 10-year smoothing spline to highlight decadal-scale trends. We supplemented our visual analyses by conducting two-tailed Student's $t$-tests on 15-year sliding windows of the annual RWI chronologies from each site to test our null hypothesis that there would be no difference in growth rates between trees growing in earthworm-free and earthworm-invaded conditions. The result of each $t$ test was reported for year 8 of the 15-year window. While this approach ordinarily would call for a one-tailed test, the use of the twotailed test allows for the identification of significant differences that did not match our expected growth 
patterns. This was particularly useful since our primary aim was to determine if an earthworm signal could be detected in tree-ring chronologies, regardless of sign. Additionally, given the large number of $t$-tests that would be required (62 15-year windows for each comparison), it would be expected that by chance alone at least some 15-year periods would be significantly different from one another. To examine the likelihood of chance significant relationships we created random time series equal in length to the chronologies under consideration and with similar means, standard deviations, and autocorrelation structures. While these artificial time series did not reflect an underlying age-structure such as in our tree-ring chronologies, the overall similar characteristics of the artificial and real time series provided a reasonable data set to test for the potential effects of multiplicity on our analysis. $T$-tests were performed as above with the number of significantly different windows calculated. This was repeated 1,000 times, noting the number of significant windows at each iteration.

Other than the presence of earthworms, the environmental conditions within each site were similar. Therefore, if the changes induced in the environment by earthworm invasion did not affect tree growth then the patterns in the three RWI chronologies from each site should be similar and our null hypothesis would stand. If earthworm activity did affect tree growth we could expect to see different growth patterns in chronologies developed from trees growing in earthworm-invaded conditions than the patterns exhibited by chronologies developed from trees growing at the mid-point and in earthworm-free conditions, thus rejecting our null hypothesis. Additional support for these analyses would be provided if the patterns of difference were similar between the two earthworminvaded sites. Following this logic we identified the potential dates of earthworm invasion at each site and stratified the RWI chronologies based on these dates. We used Pearson's correlation analyses to compare patterns in tree growth across each site before and after earthworm invasion and Fisher $r$-to- $z$ transformations to test for differences among the correlation coefficients.

Climate-tree growth analyses

We examined the climate-tree growth relationship recorded in the RWI chronologies at each site to explore potential climatic mechanisms influencing the different ring-width patterns exhibited by trees growing in earthworm-invaded conditions relative to those growing in earthworm-free conditions. We obtained precipitation data and mean, maximum, and minimum monthly temperature data from 1929-2005 for the climate station at Leech Lake dam (Easterling et al. 1996), and Palmer Drought Severity Index (PDSI) data from 1929-2005 for Minnesota State Climate Division 2 (Kalnay et al. 1996). The PDSI is a measure of soil moisture availability, with positive values indicating more moisture available and negative values indicating less moisture available (Alley 1984). We calculated seasonal values for each of these variables as follows: winter (previous year December-current year February), spring (MarchMay), summer (June-August), and fall (SeptemberNovember). Because tree growth is affected by the climate of both the current and previous years (Fritts 1976), we used Pearson's correlation analyses to construct a correlation matrix between the six RWI chronologies and all of the variables by individual month and season for the current and the previous year. We identified the variables that showed the strongest relationship to tree-growth over the entire 1930-2005 period and conducted additional correlation analyses between these variables and the RWI chronologies stratified by the timing of earthworm invasion at each site. We tested for differences in the correlation coefficients among the three chronologies from each site for the two time periods using Fisher's $r$-to- $z$ transformations.

\section{Results}

Tree-ring chronology development

We collected 126 core samples from 81 maple trees that showed no evidence of recent canopy disturbances at the six sites. Of these, we successfully crossdated 117 cores from 76 trees. The growth patterns of the 76 dated samples indicated that all of the trees had attained a canopy position by 1930, and the sample depth for each chronology was relatively constant over the period 1930-2005 (Fig. 2). The samples crossdated well over the entire record and the series inter-correlations were relatively high over the period of analysis for RWI chronologies 
(a) Ottertail

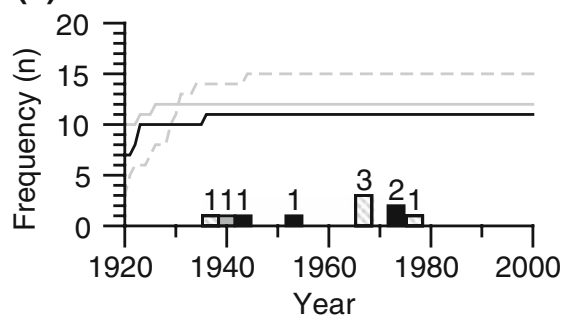

(b) Section 19

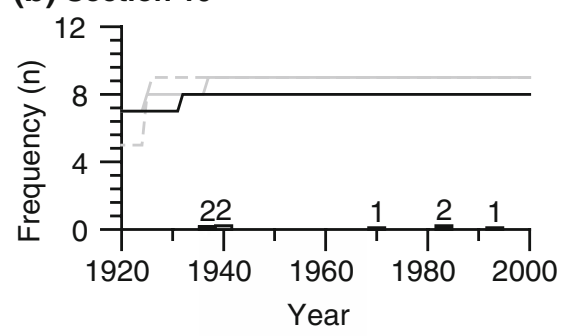

Sample depth Disturbance events by decade

- Worm-free RWI

- Mid-point RWI

- Worm-invaded RWI

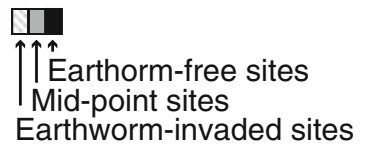

Fig. 2 Sample depth and release event frequency by decade as observed in the ring-width series of the trees sampled for the six chronologies. Numbers above the bars indicate the number of trees recording a release event in each decade

developed from trees growing in closed-canopy conditions (Table 1). We identified 18 release events across all six RWI chronologies from 1930-2005, with no more than three trees at a site recording releases in any one decade (Fig. 2).

Identification of an earthworm invasion tree-ring signature

The annual RWI chronology plots showed similarly timed periods of low growth among all six chronologies, such as the late 1930s, the mid 1950s, and the early 1980s, but of greater interest to this study were the differences identified between the chronologies developed from earthworm-free areas and earthworminvaded areas at both sites (Fig. 3). At both Ottertail and Section 19, the chronologies from the earthworminvaded areas diverged from the earthworm-free chronologies (Point 1 in Fig. 3a, b) during a period of narrower RWI for ca. 20 years at Ottertail and ca. 30 years at Section 19. After that period the
Table 1 Descriptions of the tree-ring chronologies developed from sugar maple trees growing in earthworm-free and earthworm-invaded conditions at two sites

\begin{tabular}{|c|c|c|c|c|}
\hline \multirow[t]{2}{*}{ Site } & \multirow[t]{2}{*}{ Years } & \multirow[t]{2}{*}{$\begin{array}{l}\text { No. trees } \\
\text { (series) }\end{array}$} & \multicolumn{2}{|c|}{$\begin{array}{l}\text { Series inter- } \\
\text { correlation }^{\text {a }}\end{array}$} \\
\hline & & & $\begin{array}{l}\text { Entire } \\
\text { record }\end{array}$ & 1930-2006 \\
\hline \multicolumn{5}{|l|}{ Ottertail } \\
\hline $\begin{array}{l}\text { Worm-free } \\
\text { site }\end{array}$ & 1884-2006 & 19 (19) & 0.297 & 0.336 \\
\hline Mid-point site & 1843-2006 & $12(24)$ & 0.590 & 0.587 \\
\hline $\begin{array}{l}\text { Worm-invaded } \\
\text { site }\end{array}$ & 1900-2006 & 15 (15) & 0.336 & 0.333 \\
\hline \multicolumn{5}{|l|}{ Section 19} \\
\hline $\begin{array}{l}\text { Worm-free } \\
\text { site }\end{array}$ & 1818-2006 & $12(24)$ & 0.474 & 0.512 \\
\hline $\begin{array}{l}\text { Mid-point } \\
\text { site }\end{array}$ & 1828-2006 & 9 (17) & 0.446 & 0.392 \\
\hline $\begin{array}{l}\text { Worm-invaded } \\
\text { site }\end{array}$ & 1873-2006 & $9(18)$ & 0.430 & 0.499 \\
\hline
\end{tabular}

earthworm-invaded area RWI chronologies increased relative to the earthworm-free RWI chronologies (Point 2 in Fig. 3a, b). These patterns were more evident in the smoothed RWI chronologies (lower panels in Fig. 3a, b). The $t$ tests identified several periods where the annual RWI chronologies from the earthworm-invaded areas at both Ottertail and Section 19 were significantly different than the earthworm-free RWI chronologies (bold lines in top panels of Fig. 3). Both sites showed short periods of contrasting differences early in the period considered (ca. 1944 at Ottertail and 1937 at Section 19), followed by periods of different timing and length but of the same general pattern of significantly narrower RWI initially followed by a shift to significantly wider RWI. Only one 6-year period was identified where either one of the mid-point RWI chronologies was significantly different from the earthworm-free RWI chronology, and of the 1000 randomized time series and associated $t$ tests, none showed significant differences for any of the 62 windows tested (or over approximately 62,000 trials). Our observations during previous research of the general rate at which earthworm invasion fronts advanced across these sites (ca. $10 \mathrm{~m} /$ year) indicated 
Fig. 3 Annual and smoothed ring-width index $(R W I)$ chronologies developed from trees growing in earthworm-free and earthworm-invaded conditions. Differences between the RWI chronologies were tested for using Student's $t$ tests on sliding 15-year windows with significance set at $P \leq 0.05$. The circled numbers in the lower panels indicate (1) the timing of earthworm-invasion at that site indicated by the initial departure of the earthworminvaded RWI chronologies from the reference chronologies and (2) a period of recovery by the trees growing at the invaded sites

\section{(a) Ottertail}

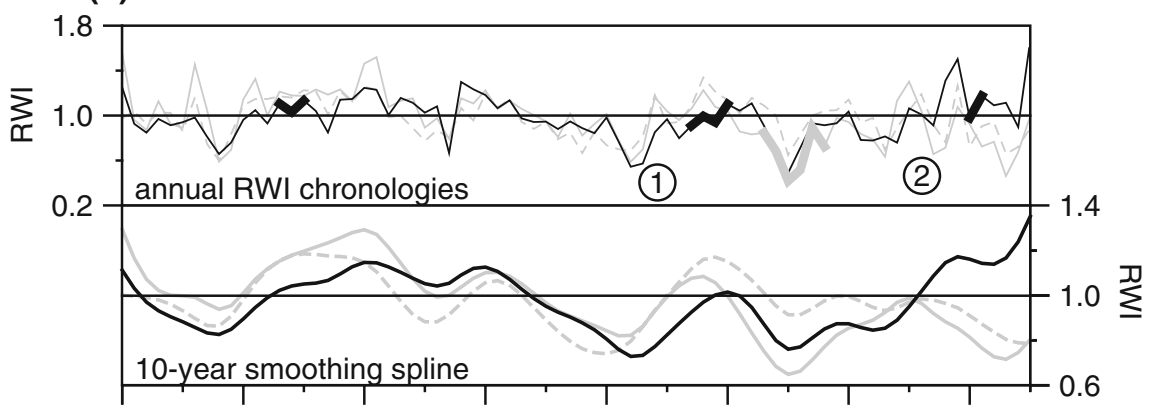

(b) Section 19

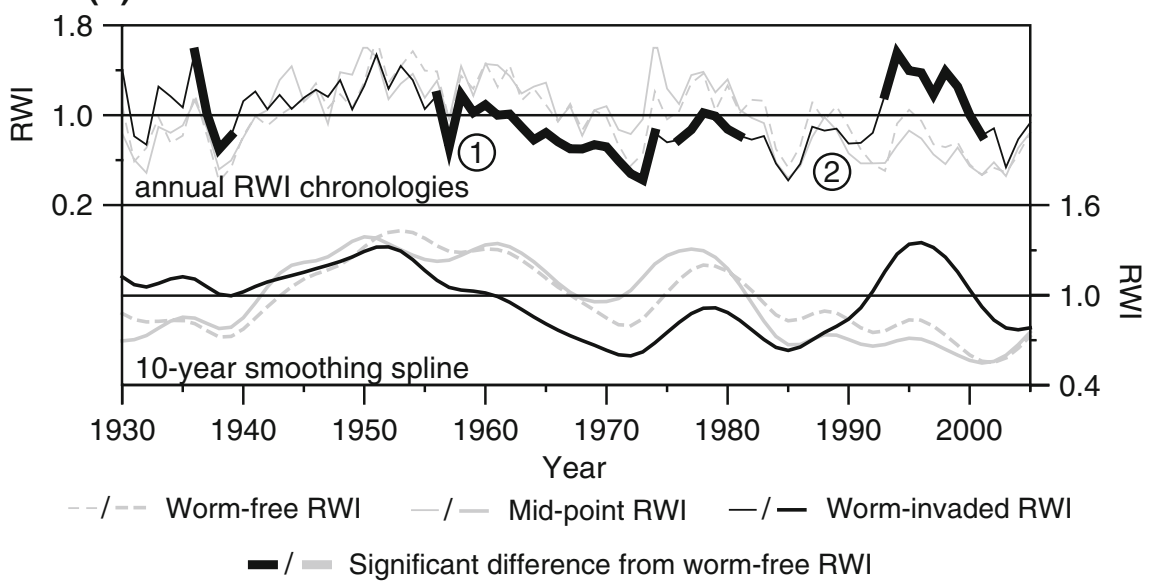

that the earliest dates most likely precluded the arrival of earthworms to either site. We therefore estimated that the earthworm invasion at Ottertail began sometime during the 1970s and at Section 19 sometime during the late 1950 s to early 1960 s.

Using the dates obtained from our visual analyses and $t$ tests to stratify the RWI chronologies resulted in striking patterns of correlation between the chronologies over different time periods that appeared to pivot most strongly on the years 1970 at Ottertail and 1960 at Section 19. At both Ottertail and Section 19 correlations between all chronologies were highly significant prior to earthworm invasion, yet after that time the correlations between the earthworm-free and earthworm-invaded RWI chronologies deteriorated while the correlations between the earthworm-free and mid-point RWI chronologies, which were earthworm-free until ca. 1998, remained strong (Fig. 4). Correlations between the earthworm-free and earthworm-invaded RWI chronologies following invasion were significantly different $(Z>2, P<0.05)$ from the correlations between all of the RWI chronologies during the earlier earthworm-free period and the earthworm-free and mid-point RWI chronologies following earthworm invasion (Fig. 4). Iteratively examining these patterns using different potential invasion dates consistently showed that the strongest and most consistent differences in tree-ring growth pivoted on the early 1970s at Ottertail and the 1960s at Section 19 , thus solidifying these as the approximate dates of invasion.

\section{Climate-tree growth analyses}

In general the RWI chronologies developed at Section 19 were more sensitive to climate than those from Ottertail, yet similar patterns emerged in the overall climate-tree growth relationships among all of the chronologies and how earthworm invasion changed these relationships. While not significant in some cases, the climate variables that showed the strongest and most consistent relationship across the six RWI chronologies were mean monthly maximum temperature and mean summer PDSI for the current 


\section{(a) Ottertail}

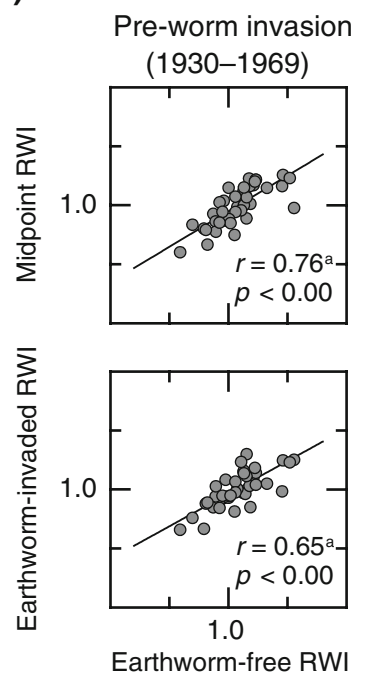

(b) Section 19

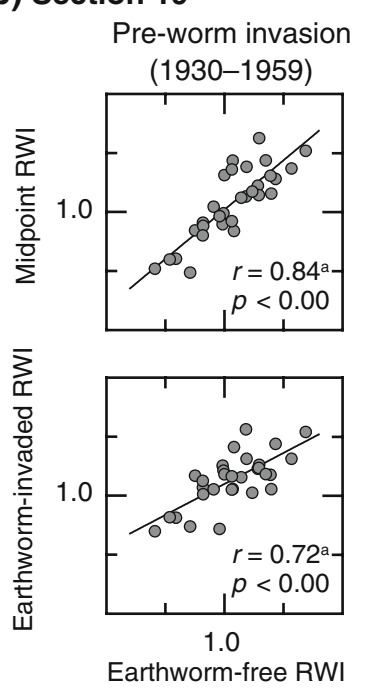

Post-worm invasion (1970-2005)
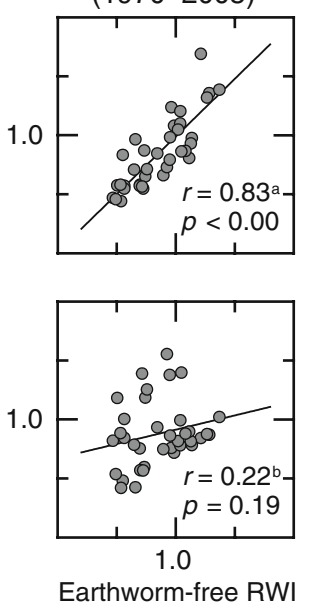

Earthworm-free RWI

Post-worm invasion (1960-2005)
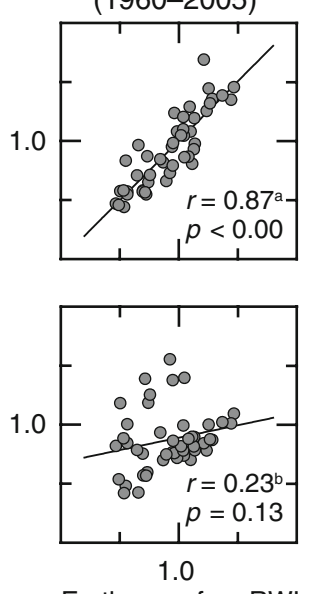

Earthworm-free RWI

Fig. 4 Correlations between RWI chronologies developed from trees growing in earthworm-free, mid-point, and earthworm-invaded conditions before and after the onset of earthworm invasion. Different superscript letters indicate significantly different correlation coefficients

year and total annual precipitation and mean monthly PDSI for the previous year. During the earthwormfree period, all six RWI chronologies were negatively correlated with the current year's mean monthly maximum temperature, and positively correlated with the current year's mean summer PDSI, the previous year's total precipitation, and previous years mean monthly PDSI (Fig. 5). After earthworm invasion, the RWI chronologies from the earthworm-free and

mid-point areas showed negative or neutral correlations with all of these climate variables, while in contrast, the earthworm-invaded sites showed positive correlations with all of these climate variables, including significantly different correlations $(Z>2$, $P<0.05)$ with the current year's mean summer PDSI and the previous year's total precipitation at both Ottertail and Section 19 (Fig. 5a, b). The shifting correlations between the chronologies developed from trees growing in the earthworm-free and midpoint areas and climate likely reflected the generally different climate conditions during these periods, with cooler, drier conditions during the 1930s to 1950s and warmer, wetter conditions prevailing during the 1960s up to the 2000s (Fig. 5c). Plotting the correlation coefficients between the RWI chronologies and the temperature and precipitation variables illustrates the contrasting directional changes in climate-tree growth relationships between the earthworm-free and earthworm-invaded sites (Fig. 6).

\section{Discussion}

Synthesizing the evidence of an earthwormrelated tree-ring signature

The use of tree rings to study the dynamics and ecological effects of biotic disturbances in forested ecosystems has a well-developed history. Researchers have analyzed patterns in tree-ring width to identify past outbreaks of defoliating insects (e.g., Blais 1958; Morin et al. 1993; Swetnam and Lynch 1993; Asshof et al. 1999; Speer et al. 2001) and have used stand age structure or non-host species growth releases to identify outbreaks of pests that commonly lead to the mortality of mature trees (e.g., Baker and Veblen 1990; Veblen et al. 1991; Perkins and Swetnam 1996; Bergeron 2000; Fraver and White 2005). Most of these studies have focused on pests that directly affect the foliage or cambium of their host trees, and only a few have investigated the effects of pest species on below-ground biomass and function of trees (e.g., Koenig and Liebhold 2003). Our research builds on this rich literature by developing a novel application of tree-ring width information to reconstruct the timing of past invasions by European earthworms into previously earthworm-free forests and to examine the effects that these ecosystem 
Fig. 5 Pearson correlations between climate and the standardized ring-width chronologies from a Ottertail and b Section 19, and $\mathbf{c}$ general climate conditions for our study area since 1930. Different letters indicate significantly different correlation coefficients. The climate variables are graphed relative to their 1930-2005 averages

\section{(a) Ottertail}
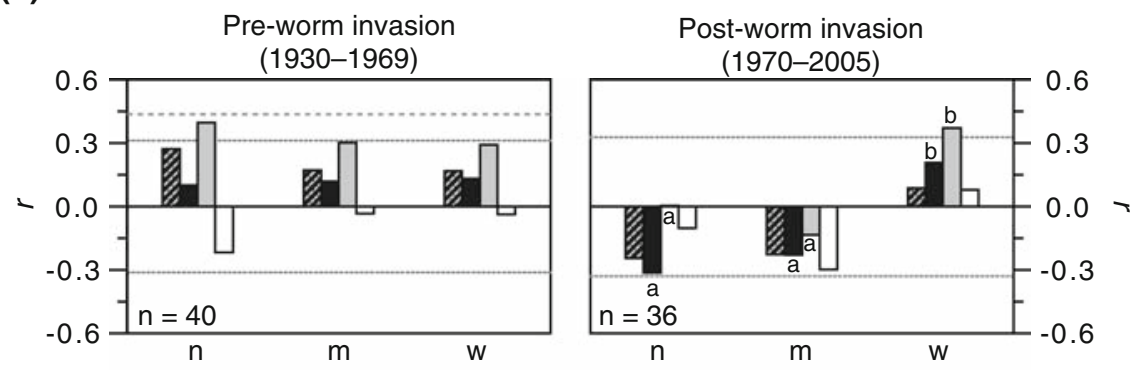

(b) Section 19

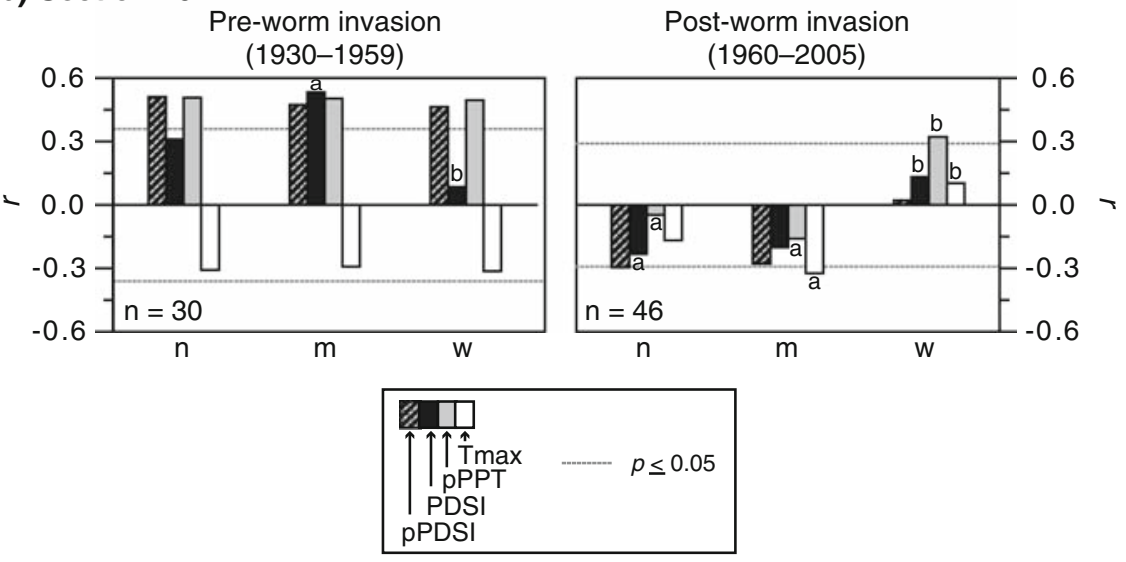

(c) Climate conditions

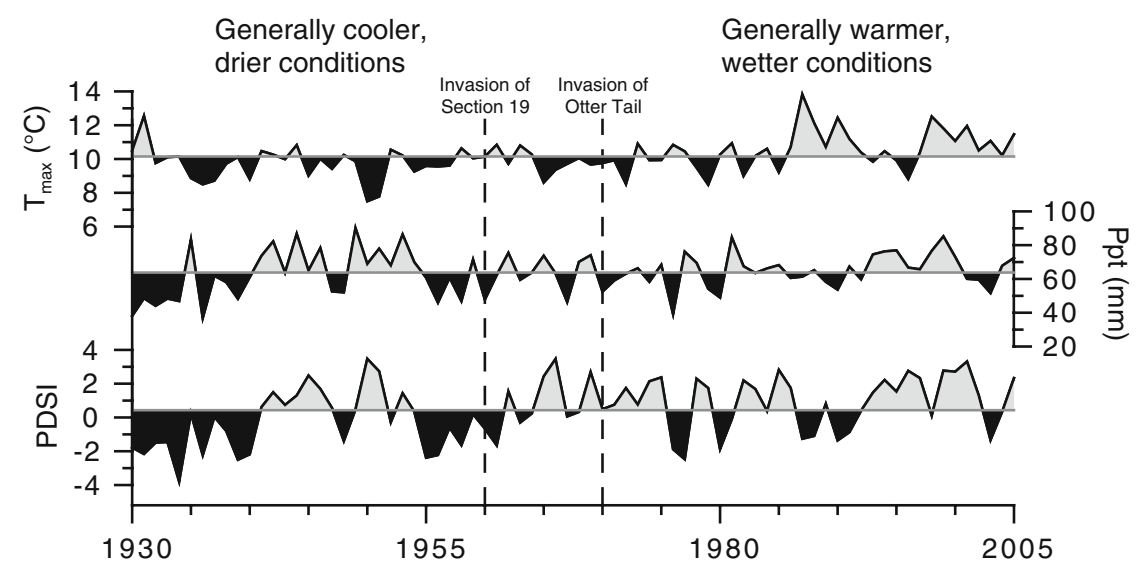

engineers have on the relationship between tree growth and climate.

The relatively high series inter-correlations of the RWI chronologies, the significant correlations among the RWI chronologies at each site, and the similar relationships between the RWI chronologies and climate variables from the earthworm-free and earthworm-invaded areas over the early periods at Ottertail and Section 19 indicate that the trees growing at these sites before earthworm invasion were responding to the same stand-scale, and perhaps regional, environmental conditions (Fritts 1976; Schweingruber 1996). Additionally, the lack of widespread release events at any of the sites suggests that no stand-wide disturbance events occurred over our period of analysis that would influence our results. Therefore, our comparisons between the RWI chronologies developed from trees growing in earthworm-free conditions to those 


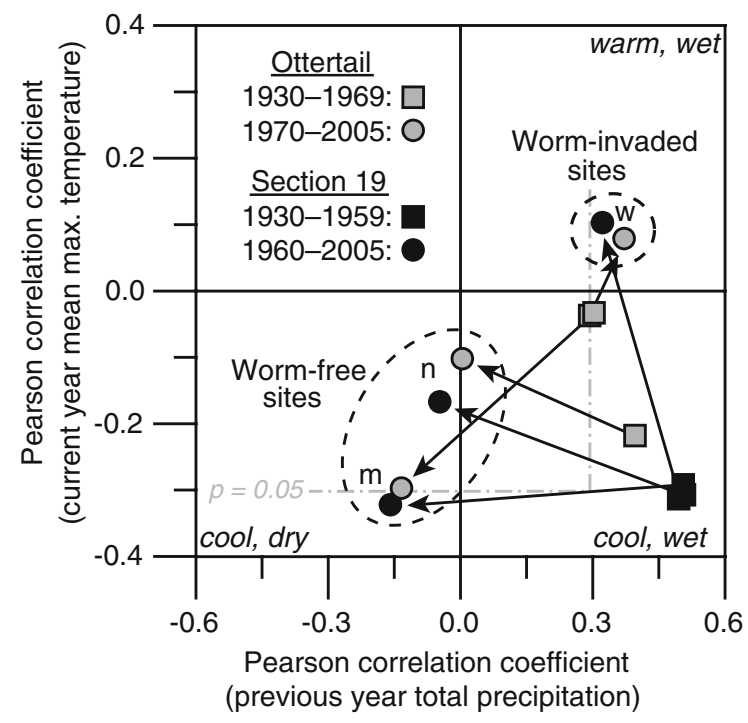

Fig. 6 Conditions promoting wider rings in trees growing in the earthworm-free sites $(n)$, mid-point sites $(m)$, and earthworm-invaded sites $(w)$ before and after earthworm invasion. The delineation of $P=0.05$ is based on the interval with the fewest years in the analyses $(1930-1959, n=30$ )

developed from trees growing in earthworm-invaded conditions is effectively using a host/non-host approach common in dendroecology studies (cf. Fritts and Swetnam 1989; Kipfmueller and Swetnam 2001).

The tree-ring signature of earthworm invasion, as identified in this study, includes three components: (1) a period of 20-30 years of reduced radial growth rates in trees growing in newly invaded areas relative to trees growing in the same stand but in earthwormfree conditions; (2) a subsequent period of increased growth by the trees in the earthworm-invaded areas relative to trees in the same stand growing in earthworm-free conditions; (3) the deterioration of the common ring-width signal between trees growing in earthworm-free and earthworm-invaded areas. It is important to note that this signature was identified through a series of complementary analyses. Taken alone, each analysis would likely be unable to identify the arrival of earthworms into these stands, yet when used in conjunction with one another they provide a clear illustration of the earthworm-related tree-ring signature and the date when earthworms first entered these sites. It should also be noted that while the results of some of our analyses are contingent on the dates of invasion estimated from the initial visual examination of the tree-ring chronologies, iterative testing of other dates consistently showed our selected dates of invasion as the point that distinguished the strongest most consistent differences between the earthworm-free and earthworm-invaded sites. Additionally, the persistent patterns of deviation identified by the $t$ test approach using the real time series, in contrast with the lack of significant differences found in the randomized trial, improves our confidence that these differences are indeed real. The sampling design attempted to control for climate (sites are similar), disturbance, and other factors that may have led to differences suggesting that the differences between chronologies are indeed evidence of the effects of invading earthworms.

The earlier invasion at Section 19 is corroborated by its geographic location and the earthworm biomass data. A primary source of earthworm invasions in northern Minnesota is the release of unused fishing bait and the intentional introduction of earthworms for the purpose stocking fishing bait (Frelich et al. 2006). The likely epicenter for the earthworm invasion fronts moving through Section 19 and Ottertail is a fishing resort on Leech Lake that was established in the 1950s. Our site at Section 19 directly borders the resort property, while the Ottertail site is separated from the resort by a paved road and several hundred yards further inland. The earthworm biomass data indicate a more advanced invasion at Section 19, with a more complete species assemblage and greater total earthworm biomass (Fig. 1a, b).

Interestingly, the mid-point chronologies at both Ottertail and Section 19 exhibited lower growth rates relative to the earthworm-free chronologies ca. 1985. While the visible leading edge of earthworm activity was at the midpoint of each site in 1998, the earthworm biomass data indicates that both D. octaedra and L. rubellus were found in front of this line. These species, and in particular L. rubellus, may affect site conditions sufficiently to initiate the early declines in tree growth that we have identified in the earthwormrelated tree-ring signature. Additional research is needed to explore the species-specific effects of earthworm invasions.

Potential mechanisms linking earthworm activity to a tree-ring signature

The tree-ring signal that we observed at our sites was not a discrete event typically associated with biotic 
disturbance agents, such as a period of defoliation (e.g., Duncan and Hodson 1958; Speer et al. 2001), but instead reflected relatively sudden and longlasting changes wrought in the growing environment of the sampled maple trees following the invasion of European earthworms into these previously earthworm-free sites. The most conspicuous and consistently observed change in forest systems after invasion by earthworms is the elimination of the $\mathrm{O}$ horizon (Gundale 2002; Bohlen et al. 2004a, c; Hale et al. 2005b; Frelich et al. 2006). The loss of the O horizon results in cascading ecological changes that are likely the primary cause of the tree-ring signature exhibited by trees growing in earthworm-invaded conditions.

Earthworms eliminate the $\mathrm{O}$ horizon by mixing the organic material of which it is composed as well as each annual litter fall material throughout the top layers of the soil profile (Ponge and Delhaye 1995; Gundale 2002). This creates an organic rich, homogenous A horizon (Burtelow et al. 1998) subject to increased rates of erosion at the exposed soil surface and an overall compaction of the soil due to the higher bulk density of earthworm casts than that of undisturbed forest soils (Hale et al. 2005b). These changes, in turn, result in decreased rates of water infiltration (Francis and Fraser 1998).

The $\mathrm{O}$ horizon of an intact northern deciduous forest floor contains the greatest amount of fine roots for understory plants, tree seedlings, tree saplings, and adult trees of the soil profile (Fisk et al. 2004). By eliminating this layer, earthworm invasions are linked to reductions in fine root mass (Fisk et al. 2004; Hale et al. 2005b) and high rates of mortality of plants in the understory community (Hale et al. 2006). In addition to the loss of fine roots, the loss of the $\mathrm{O}$ horizon disrupts mycorrhizal communities in sugar maple forests (Lawrence et al. 2003). The uptake of several important nutrients, including nitrogen and phosphorus, occur through the fine root systems of trees and their associated mycorrhizal communities (Wood et al. 1984; Nadelhoffer et al. 1985; Marschner and Dell 1994). The physiological shock that trees must experience following earthworm invasion and the loss of their fine root systems is likely the cause of the initial decrease in growth rates we identified in the ring-width chronologies developed from trees growing in earthworm-invaded conditions. Following this shock, as trees reestablish their fine roots systems, an ephemeral pulse of phosphorus and nitrogen released when the $\mathrm{O}$ horizon is first mixed into the soil profile following earthworm invasion (Scheu and Parkinson 1994a; Hale et al. 2008) would become available and could explain the increased growth rates exhibited by trees growing in worminvaded conditions. As illustrated at Section 19, however, these increased growth rates are shortlived. This likely reflects the accelerated leaching of nutrients such as nitrogen and phosphorous following their mineralization and concentration by earthworms (Steinberg et al. 1997; Bohlen et al. 2004b; Suarez et al. 2004; Szlavecz et al. 2006).

The effects of earthworm invasion on climate-tree growth relationships

Climate-tree growth relationships in northern deciduous forests vary over space and time (Graumlich 1993; Tardif et al. 2001). Trees in different canopy positions also respond to the same climate conditions differently (Orwig and Abrams 1997). It was therefore not surprising to find the strength of the relationships between the RWI chronologies and the different climate variables shifted over the period of our analyses. The inverse correlations with temperature and positive correlations with precipitation and PDSI of all six RWI chronologies during the early period indicated that the growth of these trees was largely related to drought conditions, where cool moist conditions encouraged wider rings and warm, dry conditions resulted in narrow rings. The 1930s and 1950s were very dry in this region (Karl and Koscielny 1982), and small variations in moisture and temperature likely had large effects on what may have been chronically moisture-stressed trees. In contrast, the 1960s through the early 2000s were relatively wet (mean PDSI for 1961-2001 = 1.06) and reduced the sensitivity of trees growing in earthworm-free conditions to variations in precipitation. At the same time, tree growth in the earthworminvaded areas remained significantly and positively correlated with precipitation, which one would expect for trees with poorer water status. These contrasting relationships are perhaps the result of changes in site hydrology and/or tree fine root systems due to earthworm invasion.

The $\mathrm{O}$ horizon in unaltered forests acts as a buffer between the soil and the atmosphere by moderating 
the moisture and temperature regimes of the soil surface (Kimmins 2003). The removal of this buffer leads to higher evaporation rates and less insulation from temperature extremes, and when coupled with the compaction of forest soils by earthworms (Hale et al. 2005b), results in increased runoff, decreased rates of moisture infiltration, and increased frequency and amplitude of drought conditions in the soil (Francis and Fraser 1998). The loss of the O horizon in earthworm-invaded sites therefore decreases the residence time of moisture in the forest following rainfalls by increasing runoff rates and removing the buffer provided by the decomposing organic material. In turn, this likely increases the frequency in occurrence of drought conditions at earthworminvaded areas so that tree growth may be limited by low moisture availability even during periods where the average climate conditions are relatively wet, as shown in our climate-tree growth analysis of trees growing in earthworm-invaded conditions. In contrast, an intact $\mathrm{O}$ horizon during generally wetter climate conditions may in fact prolong saturated soil conditions (sensu Hook 1984), particularly following spring melt off and rains (Payette et al. 1996; Tardif et al. 2001). This could explain the negative correlations between PDSI and tree growth in earthwormfree sites during the later period of our analyses.

The results of our climate-tree growth analyses hold potentially important implications for the effects of earthworm invasion on forests in a changing global environment. Models predict that the future climate of the Midwestern US will likely include more frequent and severe droughts (Tebaldi et al. 2006). The range of many tree species that are currently found in this region are expected to change as a result (Auclair et al. 1996), with suitable habitat for sugar maple being eliminated in Minnesota over the next century (Iverson et al. 2008). Increased sensitivity of sugar maple trees to drought conditions following earthworm invasion may accentuate and accelerate the loss of this species from the state and region if droughts do indeed become more frequent and severe.

\section{Conclusions and implications for future research}

The results of our research indicate that dendrochronology can serve as a viable tool to date past European earthworm invasions into previously earthworm-free environments and creates new opportunities to study the long-term ecological effects of earthworm invasions on North American forests. Our research also illustrates the effects that earthworm invasions have on the climate-tree growth relationships in northern hardwood forests, with important implications for forest management under changing climate conditions and drought frequency. Future research should use both tree-ring widths and chemical evidence contained in tree rings (e.g., biogenic element concentrations, isotopic ratios of nitrogen and/or oxygen) to explore if these results are consistent among forests with different stand histories and environmental settings and address in more detail how the environmental conditions created by earthworms affect the climate-tree growth relationships of trees growing in northern deciduous forests.

Acknowledgments We thank Ian Aldrich, Ruth Baker, Chaïna Bapikee, Ryan Hueffmeier, Danny Margoles, and Julia Sawa for their assistance in the field, and Kenny Blumenfeld for his insightful comments on the most recent climate predictions for Minnesota. The comments of two anonymous reviewers and Daniel Simberloff improved this manuscript.

\section{References}

Alban DH, Berry EC (1994) Effects of earthworm invasion on morphology, carbon, and nitrogen of a forest soil. Appl Soil Ecol 1:243-249

Alley WM (1984) The palmer drought severity index: limitations and assumptions. J Appl Meteor 23:1100-1109

Asshof R, Schweingruber FH, Wermelinger B (1999) Influence of a gypsy moth (Lymantria dispar L.) outbreak on radial growth and wood-anatomy of Spanish chestnut (Castanea sativa Mill.) in Ticino (Switzerland). Dendrochronologia 16-17:133-145

Auclair AND, Lill JT, Revenga C (1996) The role of climate variability and global warming in the dieback of Northern Hardwoods. Water Air Soil Pollut 91:163-186

Baker WL, Veblen TT (1990) Spruce beetles and fires in the nineteenth-century subalpine forests of western Colorado. USA Arct Alp Res 22:65-80

Bergeron Y (2000) Species and stand dynamics in the mixed woods of Quebec's southern boreal forest. Ecology 81: 1500-1516

Blais JR (1958) Effects of defoliation by spruce budworm on radial growth at breast height of balsam fir and white spruce. For Chron 34:39-47

Bohlen PJ, Groffman PM, Fahey TJ et al (2004a) Ecosystem consequences of exotic earthworm invasion of north temperate forests. Ecosystems 7:1-12

Bohlen PJ, Pelletier DM, Groffman PM et al (2004b) Influence of earthworm invasion on redistribution and retention of 
soil carbon and nitrogen in northern temperate forests. Ecosystems 7:13-27

Bohlen PJ, Scheu S, Hale CM et al (2004c) Non-native invasive earthworms as agents of change in northern temperate forests. Front Ecol Environ 2:427-435

Burtelow AE, Bohlen PJ, Groffman PM (1998) Influence of exotic earthworm invasion on soil organic matter, microbial biomass and denitrification potential in forest soils of the northeastern United States. Appl Soil Ecol 9:197-202

Consulting Voortech (2005) Measure J2X v3.2.1: the tree ring measurement program. Voortech Consulting, Holderness

Cook ER (1985) ARSTAN v6.05: chronology development and statistical analysis software. Tree-Ring Laboratory, Lamont-Doherty Earth Observatory of Columbia University, Palisades, NY

Cook ER, Peters K (1981) The smoothing spline: a new approach to standardizing forest interior tree-ring width series for dendroclimatic studies. Tree-Ring Bull 41:45-53

Duncan DP, Hodson AC (1958) Influence of the forest tent caterpillar upon the aspen forests of Minnesota. For Sci 4:71-93

Easterling DR, Karl TR, Mason EH et al (1996) United States Historical Climatology Network (U.S. HCN) monthly temperature and precipitation data. ORNL/CDIAC-87, NDP-019/R3. Carbon Dioxide Information Analysis Center, Oak Ridge National Laboratory, U.S. DoE, Oak Ridge, TN

Fisk MG, Fahey TJ, Groffman PM et al (2004) Earthworm invasion, fine-root distributions, and soil respiration in north temperate forests. Ecosystems 7:55-62

Foster DR (1988) Disturbance history, community organization and vegetation dynamics of the old-growth Pisgah Forest, southwestern New Hampshire, USA. J Ecol 76:105-134

Francis GS, Fraser PM (1998) The effects of three earthworm species on soil macroporosity and hydraulic conductivity. Appl Soil Ecol 10:11-19

Fraver S, White AS (2005) Disturbance dynamics of oldgrowth Picea rubens forests of northern Maine. J Veg Sci 16:597-610

Frelich LE (2002) Forest dynamics and disturbance regimes. Cambridge University Press, Cambridge

Frelich LE, Hale CM, Scheu S et al (2006) Earthworm invasion into previously earthworm-free temperate and boreal forests. Biol Inv 8:1235-1245

Fritts HC (1976) Tree rings and climate. Academic Press, New York

Fritts HC, Swetnam TW (1989) Dendroecology - a tool for evaluating variations in past and present forest environments. Adv Ecol Res 19:111-188

Graumlich LJ (1993) Response of tree growth to climatic variation in the mixed conifer and deciduous forests of the Upper Great-Lakes Region. Can J For Res 23:133-143

Grissino-Mayer HD (2001) Evaluating crossdating accuracy: a manual and tutorial for the computer program COFECHA. Tree-Ring Res 57:205-221

Gundale MJ (2002) Influence of exotic earthworms on the soil organic horizon and the rare fern Botrychium mormo. Conserv Biol 16:1555-1561

Hale CM, Reich PB, Frelich LE (2004) Allometric equations for estimation of ash-free dry mass from length measurements for selected European earthworm species (Lumbricidae) in the western Great Lakes region. Am Midl Nat 151:179-185

Hale CM, Frelich LE, Reich PB (2005a) Exotic European earthworm invasion dynamics in northern hardwood forests of Minnesota, USA. Ecol Appl 15:848-860

Hale CM, Frelich LE, Reich PB et al (2005b) Effects of European earthworm invasion on soil characteristics in northern hardwood forests of Minnesota, USA. Ecosystems 8:911-927

Hale CM, Frelich LE, Reich PB (2006) Changes in hardwood forest understory plant communities in response to European earthworm invasions. Ecology 87:1637-1649

Hale CM, Frelich LE, Reich PB et al (2008) Exotic earthworm effects on hardwood forest floor, nutrient availability and native plants: a mesocosm study. Oecologia 155:509-518

Holdsworth AR, Frelich LE, Reich PB (2007) Regional extent of an ecosystem engineer: earthworm invasion in northern hardwood forests. Ecol Appl 17:1666-1677

Holmes RL (1983) Computer-assisted quality control in treering dating and measurement. Tree-Ring Bull 43:69-78

Holmes RL (1999) User's manual for program EDRM v6.00P. Laboratory of Tree-Ring Research, The University of Arizona, Tucson

Hook DD (1984) Waterlogging tolerance of lowland tree species of the south. South J Appl For 8:136-149

Iverson LR, Prasad AM, Matthews SN et al (2008) Estimating potential habitat for 134 eastern US tree species under six climate scenarios. For Ecol Manag 254:390-406

Kalnay EM, Kanamitsu R, Kistler W et al (1996) The NCEP/ NCAR 40-year reanalysis project. Bull Amer Meteor Soc 77:437-470

Karl TR, Koscielny AJ (1982) Drought in the United States1895-1981. J Climatology 2:313-329

Kimmins JP (2003) Forest ecology, 3rd edn. Prentice Hall, New York

Kipfmueller KF, Swetnam TW (2001) Using dendrochronology to reconstruct the history of forest and woodland ecosystems. In: Egan D, Howell EA (eds) The historical ecology handbook: a restorationist's guide to reference ecosystems. Island Press, Washington, DC, pp 199-228

Koenig WD, Liebhold AM (2003) Regional impacts of periodical cicadas on oak radial increment. Can J For Res 33:1084-1089

Lawrence B, Fisk MC, Fahey TJ et al (2003) Influence of nonnative earthworms on mycorrhizal colonization of sugar maple (Acer saccharum). New Phytol 157:145-153

Lee KE (1985) Earthworms, their ecology and relationships with soils and land use. Academic Press, Sydney

Lorimer CG, Frelich LE (1989) A methodology for estimating canopy disturbance frequency and intensity in dense temperate forests. Can J For Res 19:651-663

Lorimer CG, Frelich LE, Nordheim EV (1988) Estimating gap origin probabilities for canopy trees. Ecology 69:778-785

Marschner H, Dell B (1994) Nutrient uptake in mycorrhizal symbiosis. Plant Soil 159:89-102

Morin H, Laprise D, Bergeron Y (1993) Chronology of spruce budworm outbreaks near Lake Duparquet, Abitibi Region, Quebec. Can J For Res 23:1497-1506

Nadelhoffer KJ, Aber JD, Melillo JM (1985) Fine roots, net primary production, and soil-nitrogen availability-a new hypothesis. Ecology 66:1377-1390 
Orwig DA, Abrams MD (1997) Variation in radial growth responses to drought among species, site, and canopy strata. Trees Struct Funct 11:474-484

Payette S, Fortin MJ, Morneau C (1996) The recent sugar maple decline in southern Quebec: probable causes deduced from tree rings. Can J For Res 26:1069-1078

Perkins DL, Swetnam TW (1996) A dendroecological assessment of whitebark pine in the Sawtooth-Salmon River region, Idaho. Can J For Res 26:2123-2133

Ponge JF, Delhaye L (1995) The heterogeneity of humus profiles and earthworm communities in a virgin beech forest. Biol Fert Soil 20:24-32

Runkle JR (1981) Gap regeneration in some old-growth forests of the eastern United States. Ecology 62:1041-1051

Scheu S, Parkinson D (1994a) Effects of earthworms on nutrient dynamics, carbon turnover and microorganisms in soils from cool temperate forests of the Canadian Rocky Mountains-laboratory studies. App Soil Ecol 1: 113-125

Scheu S, Parkinson D (1994b) Effects of invasion of an aspen forest (Canada) by Dendrobaena-Octaedra (Lumbricidae) on plant-growth. Ecology 75:2348-2361

Schweingruber FH (1996) Tree rings and environmentdendroecology. Swiss Federal Institute for Forest, Snow and Landscape Research, Paul Haupt

Speer JH, Swetnam TW, Wickman BE et al (2001) Changes in Pandora moth outbreak dynamics during the past 622 years. Ecology 82:679-697

Steinberg DA, Pouyat RV, Parmelee RW et al (1997) Earthworm abundance and nitrogen mineralization rates along an urban-rural land use gradient. Soil Biol Biochem 29: 427-430

Stokes MA, Smiley TL (1996) An Introduction to tree-ring dating. University of Arizona Press, Tucson
Suarez ER, Pelletier DM, Fahey TJ et al (2004) Effects of exotic earthworms on soil phosphorus cycling in two broadleaf temperate forests. Ecosystems 7:28-44

Swetnam TW, Lynch AM (1993) Multicentury, regional-scale patterns of western spruce budworm outbreaks. Ecol Monogr 63:399-424

Szlavecz K, Placella SA, Pouyat RV et al (2006) Invasive earthworm species and nitrogen cycling in remnant forest patches. Appl Soil Ecol 32:54-62

Tardif J, Brisson J, Bergeron Y (2001) Dendroclimatic analysis of Acer saccharum, Fagus grandifolia, and Tsuga canadensis from an old-growth forest, southwestern Quebec. Can J For Res 31:1491-1501

Tebaldi C, Hayhoe K, Arblaster JM et al (2006) Going to the extremes-an intercomparison of model-simulated historical and future changes in extreme events. Clim Change 79:185-211

Tiunov AV, Hale CM, Holdsworth AR et al (2006) Invasion patterns of Lumbricidae into the previously earthwormfree areas of northeastern Europe and the western Great Lakes region of North America. Biol Inv 8:1223-1234

USDA (1997) Soil survey of Cass County, Minnesota. National Cooperative Soil Survey, US Department of Agriculture and Minnesota Natural Resources Conservation Service, Washington, DC

Veblen TT, Hadley KS, Reid MS et al (1991) Methods of detecting past spruce beetle outbreaks in Rocky Mountain subalpine forests. Can J For Res 21:242-254

Wood T, Bormann FH, Voigt GK (1984) Phosphorus cycling in a northern hardwood forest-biological and chemical control. Science 223:391-393

Yamaguchi DK (1990) A simple method for cross-dating increment cores from living trees. Can J For Res 21:414416 